\title{
APPROACHING THE MACEDONIAN PELOPONNESE ${ }^{1}$
}

\author{
Graham SHIPLEY
}

In memory of Peter Derow (1944-2006)

The Peloponnese is at the heart of archaic and classical Greece, containing over 130 city-states (poleis) and dominating long stretches of such literary narratives as survive. Its archaeology and epigraphy have been subjected to wide-ranging investigation for over two centuries ${ }^{2}$. As early as 1851, Ernst Curtius published a brilliant reconstruction of the history, cultures, and, as we would now say, mentalités of Peloponnesian societies ${ }^{3}$. Yet the greater proportion of his two-volume work Peloponnesos concentrates on geography and topography, owing much to (but going well beyond) the data provided by Leake ${ }^{4}$ and by the Expédition Française de Morée ${ }^{5}$. Curtius includes a chapter giving an overview of the long-term history from antiquity to his own time, but himself bemoans the lack of a dedicated history of the Greek Peloponnese: 'eine anschauliche

1. This paper is slightly expanded from that delivered at Tours in October 2005. Discussions complementary to the present paper will be found in Shipley 2005 and Shipley 2006. The ideas discussed here will be developed in a forthcoming Cambridge University Press monograph. I thank very warmly the conference organizers, particularly Professor Grandjean, for their invitation to participate. Since the start of my work on the Peloponnese, the University of Leicester has awarded me leave in 1999, enabling me to take up a grant from the Copenhagen Polis Centre, the Visiting Fellowship at the British School at Athens, and an award under the Arts and Humanities Research Board Study Leave Scheme; in 2002, when the work was developed further; and in 2004-2005, allowing me to take up a British Academy Senior Research Fellowship. I gratefully acknowledge the invaluable support of all these bodies, as well as of the librarians and other staff of the BSA, the University of Leicester Library, and the Institute of Classical Studies, London. My departmental colleagues shouldered considerable burdens to facilitate these periods of leave, and I owe them a great deal.

2. On Curtius, see Calder 1996.

3. Curtius 1851-1852.

4. Leake 1830, continued in Leake 1846.

5. Blouet 1831-1838. 
Darstellung der Halbinsel in Beziehung auf ihre hellenische Geschichte ist noch von Keinem versucht worden' ${ }^{6}$. While it is tempting to re-echo his lament, it would be a Herculean task today for one scholar to cover all periods adequately, given the increase in evidence and understanding since the mid-nineteenth century.

The present paper covers a mere century and a half: the early hellenistic period. This phase of Peloponnesian history has not yet been the focus of a dedicated study, though Tarn and Walbank, for example, offer important discussions in the course of their political-military studies, and there are many relevant geographical-historical observations by in the works of Curtius, Baladié, and others 7 . My particular interest is in discovering to what extent the Peloponnese developed differently because of the actions of Macedonian warlords and, later, kings. To put it another way, I wish to know whether the Peloponnese would have developed differently without the Macedonians. The answer may also have important implications for the transition to Roman rule.

What, then, was the ancient perception of Macedonia's impact between 338 and 195 BC? Polybios goes so far as to contrast 'those times, when the Peloponnese had been utterly ruined by the Macedonian kings and still more by continued intestinal wars' (emphases added), with 'our own times, when all are in complete unison and enjoy, it is thought, very great prosperity' ${ }^{8}$. The period of disaster with which he confronts us is probably the second half of the third century. 'Ruined' (katéphtharto) is a strong claim, even if the blame is only partially being laid at the Macedonians' door; in so far as it does attach specifically to them, is it justified?

To a straightforward response in terms of political hegemony, warfare, and active intervention, we could add another framed in terms of political response and adaptation by those ruled. A picture of change and continuity in society, economy, culture, and landscape would also require us to give full weight to archaeological data in their own right, not just as a way of testing the literary sources. Archaeology can also point to changes taking place at different spatial scales (for example region, polis, and micro-environment). Did the effects of Macedonian domination vary from region

6. Curtius 1851-1852, i. 139.

7. I do not forget the contributions of travellers such as Ross 1841, Clark 1858, Wyse 1865, and Lang 1878; the work of specialists such as Gardner 1887 and Philippson 1892; the numerous publications of Ernst Meyer, W. Kendrick Pritchett, and more recently Yanis Pikoulas on topography; and of epigraphers too numerous too mention. Nor must we neglect military sources such as the little handbook of von Freyberg et al. 1944, or the compendious still inspiring British wartime geographical handbooks (Admiralty Naval Intelligence Division 1918-1919 and its successor Admiralty Naval Intelligence Division 1944-1945). I have not seen Adshead 1980 on the archaic Peloponnese.

8. 2.62.4 (trans. Paton). Walbank 1957, 267-268, on 2.62.4: the period of unity and prosperity, which P. contrasts with the second half of the third century, will be 181-146. 
to region, place to place? What were the limits of this power? Were the Macedonians compelled to modify their approach by what they encountered? To what extent were the traditions of Greek communities, and their relationships, successfully maintained? Were some changes (and indeed continuities) unconnected with the application of Macedonian power?

I cannot deal with all those questions, but will concentrate on the testimony of archaeology and landscape in order to focus briefly on four points: warfare and its effects; geography and the possibilities it offers and withholds; pottery and its implications; and archaeological field survey. I leave aside such promising areas as the variation in the spatial distribution of epigraphic finds (which reveals interesting regional differences, for example in the degree of political centralization), the evidence for building activity in towns and sanctuaries, and the evidence of urban and rural fortifications.

The last-named areas of the evidence, incidentally, tend to contradict Rostovtzeff s notion of a rather stagnant Greece. At one point in his classic work The Social and Economic History of the Hellenistic World, he declares that there was little change in thirdcentury Greece, and implies that Macedonian rule had little impact ${ }^{9}$. The physical environment, the experience of daily life, had not changed. Yet immediately afterwards he lists important social and ideological innovations-national consciousness, increased diplomacy and arbitration, euergetism, and the permeability of social class boundaries (at least in philosophical theory) ${ }^{10}$. Features such as these have led some scholars to see parallels between the hellenistic period and our own age ${ }^{11}$. Yet shortly afterwards, and surprisingly, Rostovtzeff dismisses these changes as merely exceptional palliatives that affected mainly the upper classes ${ }^{12}$ and did not 'counteract the dominant characteristic of Greek institutions, the city particularism' 13.

Rostovtzeff's judgement that élites became more dominant in this period agrees with the conclusions of more recent studies. Work on Athenian material culture, however, suggests that relations between the sexes, and between free and slave, became more open. Rostovtzeff's picture of stagnation can now be seen to be exaggerated: archaeology has revealed large numbers of new building projects. As for his other changes, it seems erroneous to dismiss them as palliatives. Diplomatic and ceremonial networks, grants of citizenship, arbitration, and so on may often have had beneficial consequences for members of all classes. Greeks living away from great centres like
9. Rostovtzeff $1953,1109$.
10. Ibid., 1109-1112.
11. See e.g. Ferguson 1973.
12. Rostovtzeff 1953, 1115.
13. Ibid., 1114. 
Athens will undoubtedly have participated, at least to some extent, in a changing public culture and new social attitudes, though admittedly in small communities the texture of public and private relationships may have been slower to change.

With reference to the main questions posed earlier, we may note that not all, if any, of the changes identified by Rostovtzeff depended a priori on the presence of Macedonian overlords.

\section{NARRATIVE}

The main phases of Macedonian domination can be defined starkly.

- 1) Formal domination began under the Argead kings Philip II and Alexander the Great, provoking two revolts and harsh clampdowns by Antipatros.

- 2) The wars between Alexander's Successors down to the 300s affected particularly Arkadia, Achaia, and the north-east.

- 3) There followed a long phase of Antigonid domination, when Demetrios I regained control in the 290s and then handed the Peloponnese over to his son Antigonos Gonatas. A Greek rising around 280 led to the re-founding of the Achaian league, and despite Spartan-Macedonian collaboration against Pyrrhos the Greeks launched the so-called Chremonidean war in the 260s.

-4) Despite the Greeks' catastrophic defeat in this war, the power balance had shifted in their favour - or maybe Gonatas simply had more urgent preoccupations - since within a few years the Antigonid tide evidently began to recede. The Achaian league began to liberate non-Achaian cities and gain new members.

- 5) Paradoxically but unavoidably, the Achaian league teamed up with the Macedonian king (or, more accurately, regent) Antigonos Doson to defeat Sparta in 222. The alliance was sustained in the 'Social' war (war of the allies - socii in Latin - against Sparta, Elis, and Aitolia) of 220-217. Philip V, however, eventually had to put Macedonia's interests first, which cost him his reputation as the 'darling' of the Greeks (hoion erômenos tôn Hellênôn, Polyb. 7.11). Conflicts between Sparta and Achaia persisted for another generation, though Philip maintained relations with both sides until the Romans, having defeated him in three wars, proclaimed Greek freedom in 196.

Despite the end of Macedonian domination, decades of conflict followed between the now-dominant Achaian league and a still independent-minded Sparta shorn of its perioikic dependencies ${ }^{14}$.

14. On change in Spartan territory, see Shipley 2000. 


\section{FORCIBLE CHANGE}

So much for the course of events. It is misleading, of course, to treat every exercise of power by any Macedonian commander as an instance of the same phenomenon. It is one thing, for example, to living within the sphere of an established king of Macedonia, quite another to be faced by a general on the move, seeking to evade or destroy his rivals. The nature of power and its probable impact were different in these cases.

Among the most obvious results of Macedonian power were the effects of war - and there must have been more clashes than we are told about in the surviving literary evidence. Their direct consequences hardly need restating. Among the heaviest casualties, if we are to believe the sources, were those suffered periodically by the Spartans and their Lakedaimonian perioikoi: for example, 5,300 'Lakedaimonians and allies' in one day in 331, against the Macedonians at Corinth; 700 Spartans and others at Mantineia against Demetrios in the late 290s 15; 5,800 'Lakedaimonians' at Sellasia ${ }^{16}$; and 4,000 Lakedaimonians at Mantineia in $208{ }^{17}$. The last two figures may include mercenaries, but the demographic impact upon Laconia may have been severe.

Indirect damage to the landscape as a result of war is not often considered in detail. It could include the disruption and environmental damage caused during and after a battle, not least from hundreds of funeral pyres requiring fuel and rendering the ground sterile for a time, or by numerous burials if they took place (cf. e.g. Pol. 4.13). Consider, too, the costs when supplies and transport animals were commandeered. In 219, Philip V went via Kleitor to Psophis, 'collecting missiles and scaling ladders from the towns through which he passed' ${ }^{18}$; did he pay for them? What of the 50,000 helots or slaves (pente myriadas andrapodôn) 19 allegedly captured by the Aitolians in southern Laconia in the late 240s? Even if the figure is dubiously large, the demographic and economic impact on Sparta and its perioikic towns may have been substantial. It is worth bearing in mind also the effects of an army, even a friendly one, passing through a territory. The transit of thousands of armed men, perhaps with a supply train, along a well-frequented route, might leave a wide trail swept clean of crops and perhaps people, and littered with discarded refuse. It would be worse when the army encamped

15. Plut., Dem., 35.1-2.

16. Plut., Cleom., 28.8.

17. Pol. 11.18.10.

18. Pol. 4.70.

19. Plut., Cleom., 18(39).3. 
in a polis's territory. The good behaviour of a Spartan expeditionary army under Agis IV in was thought remarkable ${ }^{20}$.

Apart from formal wars and battles, other calamities had short-term or longterm consequences. Political exile is an obvious case; during the fourth century and the wars of the Successors there were many cases of whole groups of citizens being displaced to another polis. To cite only a single case, Aratos of Sikyon himself was spirited away to Argos as a boy, returning years later to liberate his city and lead the Achaian league ${ }^{21}$. Politically motivated massacres took place in several towns in the war between Kassandros and Polyperchon; in one of the worst cases, at Argos in 315, a general of Kassandros burned over 500 men alive ${ }^{22}$. It is hardly necessary to mention the Aitolians and Kynaitha ${ }^{23}$. The fact that such events had happened before, notably in the years after Leuktra, does not minimize the demographic and psychological effect such a deed would have upon a small community. On the other hand, not all the above consequences of warfare were necessarily distinct in kind or scale from what could happen, and often, did, without the involvement of Macedonian armies.

On a non-catastrophic time-scale, evidence of economic consequences of Macedonian rule is often circumstantial and contestable. Tarn, while arguing against a rigid, widespread system of puppet rulers under Gonatas, supposed that, where a tyrant did govern a city, he was invariably kept in power by a garrison of mercenaries whom he, the tyrant, had to pay. In practice, one supposes, the cost might be devolved upon the rich citizens ${ }^{24}$; but I know of no direct evidence. Is it not possible, for example, that there were some Macedonian troops in garrisons? Neither is there evidence, apparently, for the systematic taxation of cities that features in Tarn's picture, though it would not be surprising if the kings creamed off some of the harbour dues of Corinth, perhaps to pay for the Acrocorinth garrison. Almost absent, too, are any signs of rural centuriation, though there are notorious cases of obliterating or restructuring urban landscapes, such as Sikyon at the end of the late fourth century. But there appears to be no evidence for the redistribution of land to veterans or supporters, in Roman or Seleukid fashion. Nevertheless, various economic consequences may have ensued upon the imposition of direct or indirect rule over a polis and its networks.

If one were to set the possible economic impact of Macedonian power alongside the disasters resulting from armed encounters, one might be led to think that much of the Peloponnese was devastated, or suffered serious damage and loss of population.

20. Plut., Agis, 14.

21. Plut., Arat., 2.

22. Diod. 19.63.2.

23. See Pol. 4.17-21.

24. Tarn 1913, 113-114. 


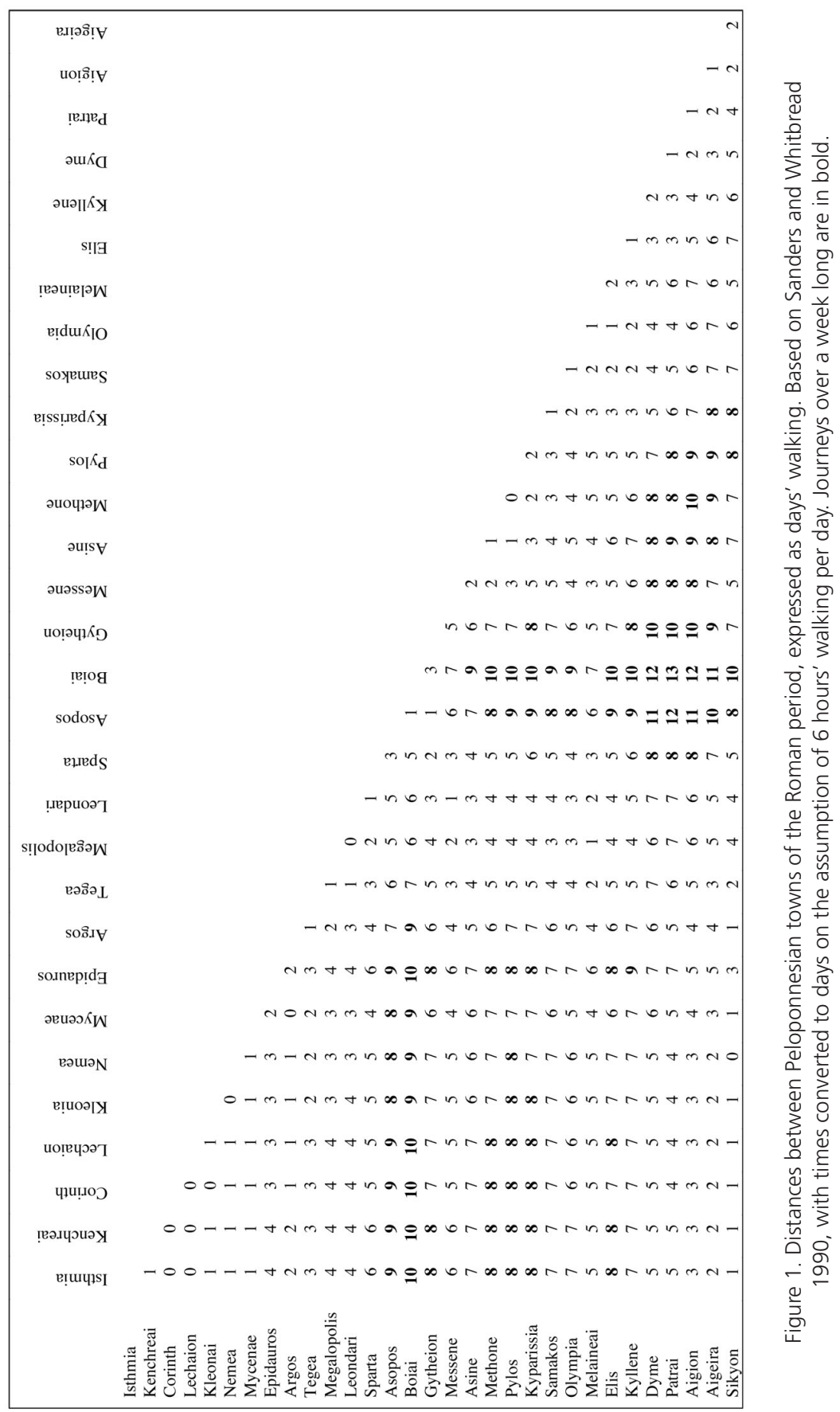


Similar things, however, had happened repeatedly in the fourth century; and most effects will have been localized and short-term; populations, like economies, can recover quickly. The severest effects were concentrated in certain regions at certain times: the north-east during the wars of the Successors, the north and north-west during the Social war, Laconia during about nine, albeit brief, invasions. If we want to examine Polybios's claim about the kings ruining the cities, I suspect we need to look at more structural features.

\section{GEOGRAPHICAL FACTORS}

In assessing the effects of Macedonian domination, we must also consider geographical constants and constraints. To begin by stating the obvious: it is a long way from Macedonia to the Peloponnese, and control can be hard to exercise at a distance. Even Acrocorinth, the Macedonians' main stronghold, controlling ingress to and egress from the Peloponnese, is badly placed for control of the far south and west of the peninsula.

Figure 1 indicates roughly how many days' land travel separates various places. The data are a reworking of those gathered by Sanders and Whitbread from the Peutinger Table, early modern travellers, and other sources ${ }^{25}$. A maximum walking day of six hours at $4 \mathrm{~km}$ per hour would suit a reasonably fit lone traveller or a small party, but an army would normally proceed more slowly. It may surprise readers to realize that while Corinth is only about three days from Aigion by land, it is about ten from Cape Malea and almost as far from coastal Messenia. Sea travel was of course often preferred, as Klaus Freitag has shown for the gulf of Corinth; but rounding Cape Malea was dangerous. Philip V's achievement in reaching Sparta from Leukas in six days was thought amazing ${ }^{26}$. Distance may be one reason (not the main one) why Sparta was never fully pacified by the Macedonians or Achaians. It may explain why Polybios describes the Messenians as trading on their remoteness to justify noninvolvement in international affairs ${ }^{27}$. Remoteness, of course, is relative. In a period when power flows from the north via Corinth, Laconia and Messenia are remote; in the late Bronze Age, however, the critical contacts were with Crete via Kythera.

25. Sanders \& Whitbread 1990.

26. Pol. 5.18. It is not quite clear whether Polybios means this, or means six days from Lechaion; but Walbank 1957, 553 ad loc. follows Holleaux 1921, 157-158 n. 8, in taking it the other way. W. gives the distance from Corinth to Argos as 33 miles, Argos-Tegea as 37. Philip probably went east of Parnon via the Platanaki pass (Bölte 1929, 1342).

27. Pol. 4.32. 


\begin{tabular}{|c|c|c|c|c|c|c|c|c|}
\hline & $1(1986)$ & 2 (1989) & $3(1991)$ & 4 (1994) & 5 (1997) & $6(2000)$ & $7(2005)$ & \\
\hline venue & $\begin{array}{l}\text { Ioánnina } \\
\text { (Epeiros) }\end{array}$ & $\begin{array}{c}\text { Ródos } \\
\text { (Dodecanese) }\end{array}$ & $\begin{array}{l}\text { Thessaloniki } \\
\text { (Macedonia) }\end{array}$ & $\begin{array}{c}\text { Mytilini } \\
\text { (NE Aegean) }\end{array}$ & $\begin{array}{l}\text { Chaniá } \\
\text { (Crete) }\end{array}$ & $\begin{array}{c}\text { Vólos } \\
\text { (Thessaly) }\end{array}$ & $\begin{array}{c}\text { Aigio } \\
\text { (Achaia) }\end{array}$ & TOTAL \\
\hline $\begin{array}{l}\text { general (exc. } \\
\text { conclusions) }\end{array}$ & $1(14 \%)$ & $2(8 \%)$ & - & $5(9 \%)$ & $7(10 \%)$ & $11(12 \%)$ & $9(8 \%)$ & $35(9 \%)$ \\
\hline Peloponnese & $1(14 \%)$ & $1(4 \%)$ & $4(11 \%)$ & $5(9 \%)$ & $6(9 \%)$ & $6(7 \%)$ & $20.5(18 \%)$ & $43.5(11 \%)$ \\
\hline $\begin{array}{l}\text { Aegean Is. } \\
\text { (incl. Crete, } \\
\text { Euboia) }\end{array}$ & $4(57 \%)$ & $7(27 \%)$ & $9(25 \%)$ & $14(26 \%)$ & $21(31 \%)$ & $14(16 \%)$ & $13(12 \%)$ & $82(21 \%)$ \\
\hline $\begin{array}{l}\text { Central } \\
\text { Greece } \\
\text { (Thesprotia, } \\
\text { Ambrakia, } \\
\text { Akarnania, } \\
\text { Aitolia), } \\
\text { Attica }\end{array}$ & - & $3(12 \%)$ & $6(17 \%)$ & $3(6 \%)$ & $7(10 \%)$ & $14(16 \%)$ & $17(15 \%)$ & $50(13 \%)$ \\
\hline $\begin{array}{l}\text { N. Greece } \\
\text { (Epeiros to } \\
\text { Thrace, incl. } \\
\text { Macedonia, } \\
\text { Thessaly, } \\
\text { Achaia } \\
\text { Phthiotis) }\end{array}$ & $1(14 \%)$ & $5(19 \%)$ & $8(22 \%)$ & $6(11 \%)$ & $5(7 \%)$ & $24(27 \%)$ & $16(14 \%)$ & $65(17 \%)$ \\
\hline $\begin{array}{l}\text { Adriatic, } \\
\text { Ionian Is., } \\
\text { Balkans, } \\
\text { Black Sea }\end{array}$ & - & $2(8 \%)$ & $3(8 \%)$ & $4(8 \%)$ & $5(7 \%)$ & $11(12 \%)$ & $16(14 \%)$ & $41(11 \%)$ \\
\hline $\begin{array}{l}\text { Asia Minor, } \\
\text { E. Med., } \\
\text { Cyprus }\end{array}$ & - & $5(19 \%)$ & $5(14 \%)$ & $8(15 \%)$ & $12(18 \%)$ & $9(10 \%)$ & $15(13 \%)$ & $54(14 \%)$ \\
\hline $\begin{array}{l}\text { Africa, Italy, } \\
\text { Sicily }\end{array}$ & - & $1(4 \%)$ & $1(3 \%)$ & $8(15 \%)$ & $5(7 \%)$ & - & $5.5(5 \%)$ & $20.5(5 \%)$ \\
\hline TOTAL & 7 & 26 & 36 & 53 & 68 & 89 & 112 & 390 \\
\hline
\end{tabular}

Figure 2a. Distribution of papers in Hellenistic Pottery Conferences (percentages in parentheses total down columns). (Dates are years of conferences, not publication.)

If distance divides, routes connect. Polybios and other authors are well aware of key routes, such as the Pheneos valley leading from Arkadia down through Achaia to the sea, often used by Spartan armies ${ }^{28}$. He also points out the role of Kephallenia as a threat to the NW Peloponnese, and elsewhere comments that, after Sellasia, Antigonos Doson continued to hold little Orchomenos contrary to his agreement with the Achaians, 'wishing, as I think, not only to be master of the entrance into the Peloponnese [sc. by possessing Corinth], but to safeguard his interests in the interior' ${ }^{29}$.

28. e.g. Meyer 1975.

29. 4.6, trans. Paton. 


\begin{tabular}{|c|c|c|c|c|c|c|c|}
\hline Korinthia, Sikyonia & Achaia & Eleia & Arkadia & Messenia & Laconia & Argolis & Peloponnese \\
\hline $\begin{array}{l}\text { Isthmia (4) } \\
\text { Sikyon }\end{array}$ & $\begin{array}{l}\text { Aigion (3) } \\
\text { Dyme } \\
\text { Keryneia } \\
\text { Patrai (3) }\end{array}$ & $\begin{array}{c}\text { Elis (10) } \\
\text { Olympia (2) } \\
\text { Bouchióti }\end{array}$ & $\begin{array}{c}\text { Lousoi (4) } \\
\text { Phigaleia }\end{array}$ & $\begin{array}{c}\text { Messene (3) } \\
\text { Pylos }\end{array}$ & $\begin{array}{c}\text { Antidragonéra } \\
\text { Geronthrai } \\
\text { Sparta (2) }\end{array}$ & $\begin{array}{l}\text { Argos (2) } \\
\text { Epidauros }\end{array}$ & \\
\hline $2(5)$ & $4(8)$ & $3(13)$ & $2(5)$ & $2(4)$ & $3(4)$ & $2(3)$ & $18(42)$ \\
\hline
\end{tabular}

Figure 2b. Coverage of Peloponnesian sites in Hellenistic Pottery Conferences, by number of sites (number of papers in parentheses). No papers cover sites in Triphylia; two further papers cover the Peloponnese in general (A. Rizakis \& Touratsoglou forthcoming; Alexandropoulou forthcoming).

In fact Orchomenos, though this fact does not seem to receive the attention due to it, controls one of the main routes into Arkadia from the north-east.

Another geopolitical factor, of which ancient writers were aware, is the presence or absence of good harbours. Freitag corrects several misconceptions: the absence of naval facilities may cause a coast to be viewed as alimenos ('harbourless'), but this does not mean its inhabitants did not put to sea to fish, or that warships could not anchor ${ }^{30}$. However, in broad terms some areas may have interacted with the wider world less than others because of a limited number of outlets. From archaeological evidence it now seems likely, for example, that Spartan maritime contacts flowed almost entirely through Gytheion and only minimally through the ports of the eastern Parnon seaboard. Eleia, too, may have relied chiefly on the port of Kyllene ${ }^{31}$, or on Achaian and Messenian harbour towns.

\section{IMPLICATIONS OF CERAMIC EVIDENCE FOR REGIONAL VARIATION IN TRADE}

Little has so far been done to synthesize the 'material culture' of the hellenistic world, or even the Greek mainland, in terms that would satisfy archaeologists of other places and periods. Ideally we should aspire to reach a point where we can debate fruitfully about changes in social relations on the basis of excavated assemblages. Much pottery from closed deposits has been published, but often from graves or monumental fills, but rarely from domestic contexts. Coverage of the Peloponnese has been thin and fitful. Consider, for example, the contents of the seven 'Scientific Meetings on Hellenistic Pottery' so far held (figure $2 a-b$ ). There is a frustrating correlation between the location of the meeting and the coverage of the surrounding areas. Peloponnesian

30. Freitag 1999b.

31. Gehrke 1986, 103-104. 
topics received good coverage for the first time only in the meeting at Aigion in 2005.

Despite these problems of the data, we can make something of cases where stylistic links between regions are identified ${ }^{32}$. A simple comparison reveals important patterns in regional and extra-Peloponnesian interactions. In Korinthia, outside contacts seem to decline after C4 ${ }^{33}$. In Achaia, the material seems more cosmopolitan the larger the centre. Small centres (including pre-Roman Patrai) have wares either of local character or linked to the gulf and to central and western Greece ${ }^{34}$. In Eleia, pottery has a strongly regional character, surprisingly given the international profile of the Olympics; such outside links as exist are with the gulf of Corinth and Athens ${ }^{35}$. In Arkadia, Lousoi is unlikely to be typical, but shows links with the north Peloponnese and not the south; there is as yet no mention of material from outside the Peloponnese, though some plaques may have Italian connections ${ }^{36}$. In Messenia, the city of Messene has a strongly localized material record, whereas the coastal towns are more cosmopolitan ${ }^{37}$. Perhaps surprisingly, Laconia shows more awareness of external styles than in Eleia and Messenia, but here more closely linked to the Aegean world and Magna Graecia than to the Peloponnese ${ }^{38}$. Finally, in Argolis, there seems to be more interaction with the Aegean world than we find in the gulf of Corinth; unsurprisingly, there is interaction with NE Peloponnese ${ }^{39}$.

The data seem to point to the existence of two or more different 'Peloponneses', in more than one sense. The first comparison to make is between, on the one hand, regions regarded by the pottery experts as generally conservative and inward-looking in their ceramic styles (Eleia, the smaller towns of Achaia and Arkadia, and inland Messene)

32. For reasons of space, I do not discuss the data in the works cited in this paragraph, which do not necessarily hold the views presented here.

33. Anderson-Stojanović 1997; Anderson-Stojanović 2000; Anderson-Stojanović 2004; Anderson-Stojanović forthcoming.

34. Dekoulakou forthcoming (Keryneia); Papakosta forthcoming (Aigion); Kyriakou 1994 and Kyriakou forthcoming (Patrai); Vasilogamvrou et al. forthcoming (Dyme).

35. Georgiadou 2000; Iliopoulos \& Kanellopoulos forthcoming; Kastler 1997, esp. 23, and Kastler 2000; Katsarou \& Mourtzini forthcoming; Leon-Mitsopoulou 1994, esp. 166-169; Rogl 1997; Schauer 1997, 24, 30 (Olympia); Themelis 1994, 157 (tomb at Bouchioti), cf. SEG, 46, 456 with Stroud ad loc.; Vasilakis \& Koutsoubeliti forthcoming.

36. Mitsopoulou-Leon 2000 [1989], 23-28 passim; Mitsopoulou-Leon 1990; Rogl 2004.

37. Danali forthcoming; Giuliani forthcoming; Themelis 2004, 427-429.

38. Langridge-Noti \& Prent forthcoming; Raftopoulou 2000 passim, esp. 425. I am grateful to Elizabeth Langridge-Noti for a pre-print of her paper.

39. Danali 1994, 268-269; Proskynitopoulou 2000, esp. 401-402; Zehbe 1988. 
and, on the other, those displaying active links with the outside world (Corinth, Dyme, the Messenian harbour towns, and inland Laconia including Geronthrai, the only dependent perioikic polis that has been studied). Corinth, however, may have been less actively networked after c. 300, perhaps because of the Macedonian occupation of 338243. A second comparison reveals different directions of contact. There appears to be a northern and north-western culture sphere along the gulf of Corinth and extending into Eleia and northern Arkadia. By contrast, in Laconia and coastal Messenia the links with the eastern Mediterranean and Magna Graecia are stronger.

Partly, no doubt, such differences have to do with geophysical constants rather than short-term geopolitics. The broad lines of physical relief can be better appreciated by inverting a map of the Peloponnese (a trick famously played by Braudel). Within the narrow confines of an area roughly equal to Wales, or to Massachusetts, the great 'fist' of mountains in northern Arkadia dominates the entire peninsula, forcing land travellers to take a circuitous way round or attempt lofty passes. The lofty chain running down the east coast to Cape Malea delays contacts between the western two-thirds of the Peloponnese and the east. The furrows of the rivers Eurotas and Alpheios, by contrast, unite opposite corners of the peninsula, facilitating military and trade contacts. These and other topographical constants play a large part in shaping human relationships and movements, as well as in the development of a 'sense of place' that merits investigation in its own right ${ }^{40}$. More importantly for our present investigation, they may have limited the directions and intensity of Macedonian control over large areas of the Peloponnese, as well as conditioning the responses of Greek communities. Conversely, when we observe changes in the orientations of cultural links, we may be seeing changes quite independent of military-political histories.

If stylistic links can be regarded as tracers for the movement of goods, ideas, or people, they will be important for our interpretation of Peloponnesian history. Such phenomena, however, may have little to do with Macedonian rule.

\section{EVIDENCE FROM SURVEY DATA}

Another area where new data may help us begin to approach social evolution is that of archaeological field survey. I present the data, and particularly their chronological markers, in the form in which project directors have published them, but with the caveat that elsewhere in this volume John Bintliff questions the validity of many dates attributed to hellenistic survey data.

In some areas, dense classical occupation of the rural landscape appears to continue. In Korinthia, the EKAS survey up to the year 2000 found hellenistic material

40. For preliminary thoughts along these lines, see Shipley 2006. 
at most findspots ${ }^{41}$. A continuing, relatively dense spread of nucleated settlements appears to have existed in Eleia-Triphylia, where there are considerable numbers of hellenistic sites with no ancient name, most of which cannot have been poleis ${ }^{42}$. The much earlier Peneios valley survey, too, found predominantly hellenistic sites ${ }^{43}$. This seems consistent with Polybios' famous observations on the strength of Eleia's rural élite. The data perhaps suggest a reinforcement of the scattered settlement that was a feature of Eleia earlier. To over-simplify somewhat, we may characterize Eleia as a landscape that had changed little.

In other areas the hellenistic period brings change. At Asea ${ }^{44}$ and Messenian Pylos 45 a rise in small farms begins earlier, in about the fourth century. Similarly, in southern Argolis, there is a phase of dispersal during the later fourth and earlier third centuries, with increased use of storage pottery. At Berbati-Limnes in central Argolis, similar changes were detected with a slightly later chronology: a wave of new settlement at the edges of the inhabited area around 30046. The evidence from north-central Laconia points to a recolonization of marginal land again on the same, slightly later chronology. In the territory of Dyme in Achaia, the change is slightly later still: data suggest a significant recolonization of the landscape in the early or middle hellenistic period, during the third or second century 47 .

In some regions, dense rural settlement has been linked to urban growth. This may be the case in Sparta, where the central polis settlement was expanding and gaps in it were being filled in ${ }^{48}$. At Berbati-Limnes, the surveyors link the early hellenistic rise in rural sites to the refoundation of nearby Mycenae. In Achaia, Dyme and its territory appear to flourish in parallel 49 .

In some areas the wave of new settlement is short-lived. In southern Argolis there is a marked fall in the numbers of small farmsteads after only a couple of generations, around 250 50. In Berbati-Limnes the fall is believed to have happened

41. Gregory et al. 1998.

42. Roy 2004, 489-90; Nielsen 2004.

43. Leekley \& Noyes 1976, 99; cf. esp. Fraser 1969-1970, at 14-15; and now Whitley 2002-2003, at 36 .

44. Forsén et al. 1996, at 91; Forsén \& Forsén 2003, 334.

45. Davis et al. 1997, at 455-457.

46. Penttinen 1996, at 229, 271-272, 279-281.

47. Rizakis 1992, 68-69.

48. Kourinou 2000, 89-95, 243-246, 279-280, 285-286.

49. Lakakis \& Rizakis 1992, 70 and n. 10.

50. Jameson et al. 1994, 383-384, 391, 393-394, etc. 
by 200 . There is decline in the Patrai area during the hellenistic period as a whole ${ }^{51}$. Similar downturns in or after the early hellenistic period are seen at Nemea ${ }^{52}$, around Megalopolis ${ }^{53}$ and in its southern territory ${ }^{54}$, and on Methana ${ }^{55}$. In the territory of Dyme, however, contraction of settlement begins and ends later than elsewhere, just as the expansion began later too ${ }^{56}$.

Decline was not universal, however. In the Laconia Survey data, there is no clear evidence of a decline in site numbers during the hellenistic period ${ }^{57}$; neither do Asea or Pylos evince such a change.

The survey data also tend to confirm the picture of long-term increasing domination of landholding by the élite, possibly through intensified or new relations of dependency involving slaves, serfs, or poor freemen ${ }^{58}$. But change is not uniform; élite domination can be read from the survey data only in certain regions and with variations both between regions and even within some survey project areas ${ }^{59}$.

It is against this background that we should view the stasis (civil conflict) that was all too common in the early hellenistic period. Fuks wanted all stasis in this period to be more or less revolutionary in intent; but we must break up the phenomenon. Without going into detail, I suggest that a more useful approach than Fuks's seven classes of socio-economic revolution (some of which have only one member) 60 may be to think in terms of different though overlapping kinds of stasis, such as are clearly visible in Gehrke's survey. In one kind of stasis, ideological difference plays a major part; in another, allegiance to different powers is the main issue. There is stasis as an independence movement; there is stasis actively fomented from outside. Only some of these need have a socio-economic cause or reflect changes in the power of the élite. What they may have in common, depending on our interpretation of the sources and archaeological data, is that the push for change may not, after all, have come from below but involve only relatively well-off groups among the élite, such as Ostwald's not-quite-rich oligarchs (defined by their lack of ready money rather than by the extent

51. Papagiannopoulos \& Zachos 2000, 145-146.

52. Wright et al. 1990, at 616-617.

53. Roy et al. 1989, at 149; Lloyd 1991, at 189-190.

54. Pikoulas 1988, 231-232.

55. Gill et al. 1997.

56. Lakakis \& Rizakis 1992, at 68-69; Petropoulos \& Rizakis 1994, at 190-192 (tables 1-2), 198.

57. Shipley 2002b, esp. 274-288, 310-312, 322-326.

58. Shipley 2002a.

59. More clarification can be expected from research currently being undertaken at the University of Leicester by Daniel R. Stewart.

60. Fuks 1974, at 71-76. 
of their property) wanting the privileges they felt were their due ${ }^{61}$. Again, neither the phenomenon of stasis (which is not new) nor the changes in economic relations (which are varied in date and kind) need have anything to do with the Macedonian presence, though Macedonian rule may have exacerbated tensions within the politically active class, and given a focus.

\section{POWER}

How we see Macedonia impacting on élites depends on how we conceive the operationalization of power. Taking our cue from modern students of power such as Steven Lukes and John Scott ${ }^{62}$, we find it helpful to consider different kinds of power: for example, first, power acting efficaciously upon communities; second, power operating more subtly through psychological and interpersonal means - what some have called 'non-decision-making' power ${ }^{63}$. It is not hard to map this simple typology onto the third century. Indirect power would include, for example, support through the king's Friends for a particular faction within a polis; intervention to support a particular constitutional set-up; and subtler forms such as euergetism. On Tarn's picture, Antigonos Gonatas viewed Megalopolis as a forward line of defence against Sparta, delegating the task to an ally ${ }^{64}$; but are we sure that containment of Sparta was the main factor of Macedonian policy in southern Greece?

Moving on from top-down power, and recalling the kinds of imperial dialogue recently explored by $\mathrm{Ma}^{65}$, we can also conceive of the power relationship as a twoway process, in which the Greek communities used both overt negotiation and covert manipulation to improve their position vis-à-vis the hegemon. We may recall here the strength of local political and constitutional traditions that emerges clearly from Gehrke's work on stasis and on das dritte Griechenland ${ }^{66}$. In short, the dynamic character of the Greek poleis necessitated a flexible response from Macedonian wielders of power.

For the future, more work is needed on the construction and development of regional and sub-regional identities in the Peloponnese, and on the possible tension between belonging to a polis and belonging to a sub-regional or regional entity.

61. Ostwald 2000, passim.

62. e.g. Lukes 2004; Scott 2001.

63. Scott 2001, 8, 58-59.

64. Tarn 1913, 67, 276, 394, etc.

65. Ma 1999.

66. Gehrke 1985; Gehrke 1986. 
Undoubtedly, studies of spatial theory, viewing, and regional identity in other places and periods can inform our study of ancient Greece ${ }^{67}$.

\section{CONCLUSION}

Local and regional tradition, as well as geography and distance, conditioned the manifestations and impact of Macedonian power. It would be misleading to describe the situation of the Peloponnese as that of a province within an empire, though it is how the region is, implicitly rather than explicitly, presented in military-political histories. When considering whether the Peloponnese with which Philip II had to deal was the same as the Peloponnese that confronted Philip V and the Romans, we should not only recognize that there were changes, such as an intensification of dependency relations and a partial shift in power from Sparta to the north. We should also acknowledge the persistence of deeply rooted relationships among and between groups of people making up the Greek city-states, and should consider how these relationships affected the internal and external political actions taken by citizens or magistrates. While it is true that social relationships were sometimes exploitative ${ }^{68}$, or set in a constitutional milieu that was oligarchic in temper even if democratic in name, it is not our task to condemn. Rather, we must try to understand how a dynamic intrapolis tradition fed into inter-polis relationships. We can, if we choose to do so, lament what Tarn and Rostovtzeff call polis particularism - even Walbank in his Aratos regrets that while Kleomenes III of Sparta stood for the particularism of the polis, Aratos of Sikyon stood for the particularism of the league. Alternatively, we can follow Gruen's line: Greek disunity 'was the curse of Hellas from the beginning. It was also the very life-blood of her history' 69 .

67. Cf. the works of the humanistic geographer Yi-Fu Tuan (e.g. Tuan 1974a; Tuan 1977; Tuan 1974b), or Conforti's study of the identity of New England (Conforti 2001). Issues of regional identity will be explored in Elton and Reger eds forthcoming; I am grateful to Gary Reger for discussions of the volume in advance of publication. One might also consider Ernst Gombrich's notion of the 'beholder's share', applicable to landscape no less than to art (cf. Gombrich 2000, part 3).

68. On dependent labour in the hellenistic Peloponnese, see e.g. Shipley 2002a, 178-179.

69. Gruen 1984, 437. 


\title{
SHIPLEY, 'APPROACHING THE MACEDONIAN PELOPONNESE'
}

\author{
Abbreviations

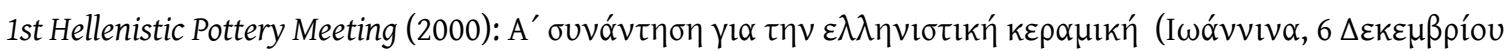 \\ 1986), 2nd edn. Rodos: Archaiologiko Institouto Dodekanisou.

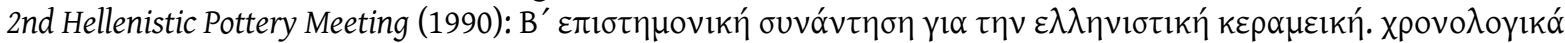

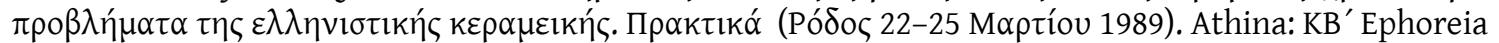 \\ Proïstorikon kai Klassikon Archaiotiton, Rodos/Tameio Archaiologikon Poron kai Apallotrioseon/ \\ Nomarchia Dodekanisou, Dimos Rodou.

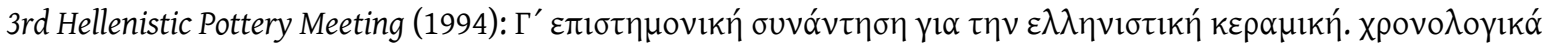

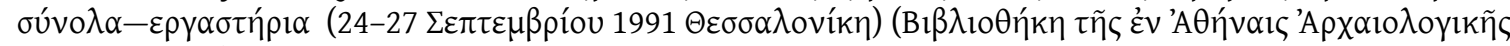

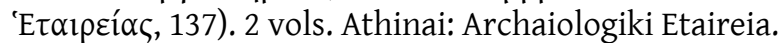

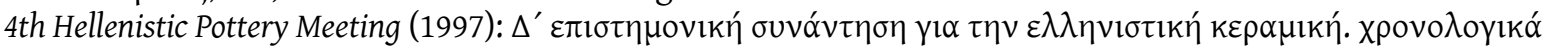

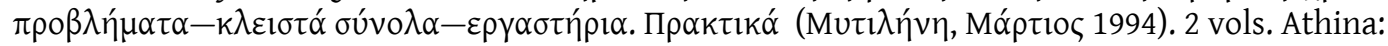 \\ Ypourgeio Politismou, K' Ephoreia Proïstorikon kai Klasikon Archaiotiton.

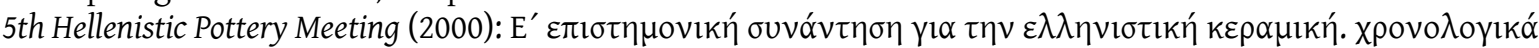

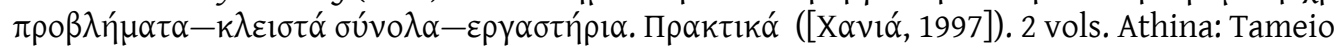 \\ Archaiologikon Poron kai Apallotrioseon.

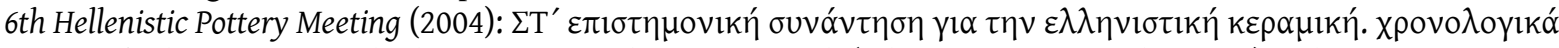

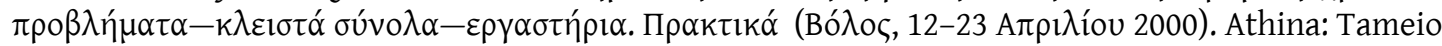 \\ Archaiologikon Poron kai Apallotrioseon.

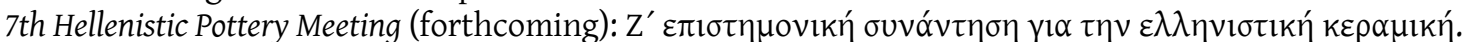

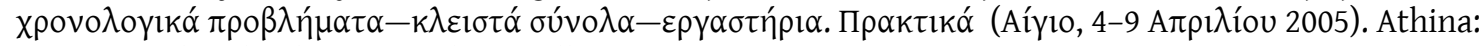 \\ Tameio Archaiologikon Poron kai Apallotrioseon.
}

\section{References for Shipley, 'Approaching the Macedonian Peloponnese'}

Admiralty Naval Intelligence Division (1944-5): Greece (Geographical Handbooks, B.R. 516, 516 A-B). 3 vols. [London]: [Admiralty] Naval Intelligence Division.

Admiralty Naval Intelligence Division, Geographical Section, (1918-19): A Handbook of Greece. 3 vols. London: Admiralty/War Office.

Adshead, K. (1980): Politics of the Archaic Peloponnese. The Transition from Archaic to Classical Politics. Aldershot: Avebury Publishing Co.

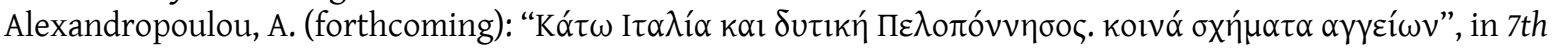
Hellenistic Pottery Meeting, [unpublished abstract].

Anderson-Stojanović, V. R. (forthcoming): "Pottery from destruction deposits of the Rachi settlement at Isthmia ca. 200 BC", in 7th Hellenistic Pottery Meeting, [unpublished abstract].

Anderson-Stojanovic', V. R. (1997): "A third century BC deposit from the south slope cistern in the Rachi settlement at Isthmia", in 4th Hellenistic Pottery Meeting, 13-19, pls 1-10.

Anderson-Stojanovic', V. R. (2000): “Corinthian West Slope pottery from Isthmia", in 5th Hellenistic Pottery Meeting, 381-5, pls 203-4.

Anderson-Stojanovic', V. R. (2004): "Dinner at the Isthmus. hellenistic cooking ware from the Rachi settlement at Isthmia", in 6th Hellenistic Pottery Meeting, 623-30, pls 303-6.

Blouet, A. (1831-8): Expédition scientifique de Morée, ordonnée par le gouvernement français. architecture, sculptures, inscriptions, et vues du Péloponnèse, des Cyclades et de l'Attique (Expédition scientifique de Morée). 3 vols. Paris: Firmin Didot.

Bölte, F. (1929): "Sparta”, RE ${ }^{2}$ iii. 2. 1265-528.

Calder, W. M., III (1996): “Curtius, Ernst (1814-96)”, in N. T. de Grummond (ed.), An Encyclopedia of the History of Classical Archaeology, i. (Westport, Conn.: Greenwood Press), 341-2.

Clark, W. G. (1858): Peloponnesus. Or Notes of Study and Travel. London: Parker.

Conforti, J. A. (2001): Imagining New England. Explorations of Regional Identity from the Pilgrims to the Mid-twentieth Century. University of North Carolina Press.

Curtius, E. (1851-2): Peloponnesos. eine historisch-geographische Beschreibung der Halbinsel. 2 vols. Gotha: Justus Perthes.

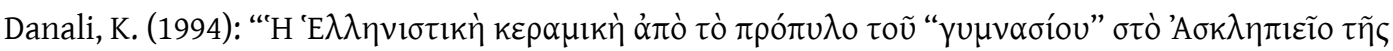

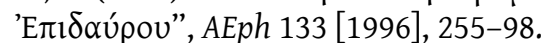

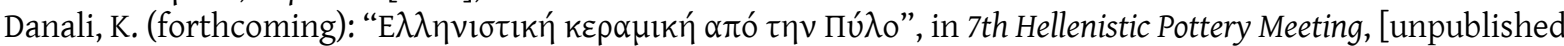


abstract].

Davis, J. L., Alcock, S. E., Bennet, J., Lolos, Y. G., and Shelmerdine, C. W. (1997): “The Pylos Regional Archaeological Project, part I. overview and the archaeological survey", Hesp. 66.3, 391-494, pls 85-92.

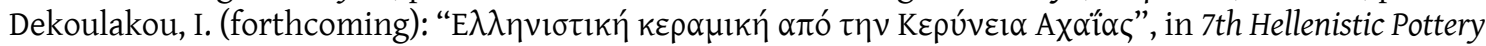
Meeting, [unpublished abstract].

Elton, H., and Reger, G. (eds) (forthcoming): Regionalism in Hellenistic and Roman Asia Minor (Trinity College, Hartford CT, 22-24 August 1997). Bordeaux: Ausonius.

Ferguson, J. (1973): The Heritage of Hellenism (Library of European Civilization). London: Thames \& Hudson.

Forsén, J., and Forsén, B. (2003): The Asea Valley Survey. An Arcadian Mountain Valley from the Palaeolithic Period until Modern Times (Acta Instituti Atheniensis Regni Sueciae-Skrifter utgivna av Svenska Institutet i Athen, series in $\left.4^{\circ}, 51\right)$. Stockholm.

Forsén, J., Forsén, B., and Lavento, M. (1996): “The Asea Valley Survey. a preliminary report of the 1994 season", OAth 21, 73-97.

Fraser, P. M. (1969-70): “Archaeology in Greece, 1969-70”, AR 16, 3-31.

Freitag, K. (1999): Der Golf von Korinth. historisch-topographische Untersuchungen von der Archaik bis in das 1.Jh. v. Chr. (Quellen und Forschungen zur antiken Welt, 34). München: Tuduv; repr. 2000, 2001.

Fuks, A. (1974-5): "Patterns and types of social-economic revolution in Greece from the fourth to the second century BC", AncSoc 5-6, 51-81; repr. in A. Fuks, Social Conflict in Ancient Greece (Leiden/Jerusalem: Brill/Magnes Press, The Hebrew University, 1984), 9-39.

Gardner, P. (1887): Peloponnesus (A Catalogue of the Greek Coins in the British Museum). London.

Gehrke, H.-J. (1985): Stasis. Untersuchungen zu den inneren Kriegen in den griechischen Staaten des 5. und 4. Jahrhunderts v. Chr. (Vestigia, 35). München: Beck.

Gehrke, H.-J. (1986): Jenseits von Athen und Sparta. das dritte Griechenland und seine Staatenwelt. München: Beck. Georgiadou, A. (2000): "Hellenistische Keramik aus Elis", in 5th Hellenistic Pottery Meeting, 386.

Gill, D. W. J., Foxhall, L., and Bowden, H. (1997): "Classical and hellenistic Methana", in C. Mee and H. Forbes (eds), A Rough and Rocky Place. The Landscape and Settlement History of the Methana Peninsula, Greece (Liverpool Monographs in Archaeology and Oriental Studies; Liverpool: Liverpool University Press), 6276.

Giuliani, A. (forthcoming): "Hellenistic pottery from the fountain-house of Arsinoë in Messene", in 7th Hellenistic Pottery Meeting, [unpublished poster abstract].

Gombrich, E. H. (2000): Art and Illusion. A Study in the Psychology of Pictorial Representation, 2nd edn. Princeton: Princeton University Press.

Gregory, T. E., and others (1998), 'Eastern Korinthia Archaeological Survey', http://eleftheria.stcloudstate.edu/eks (updated 26 Nov. 2001). Accessed 25 Feb. 2003

Gruen, E. S. (1984): The Hellenistic World and the Coming of Rome. 2 vols. Berkeley-Los Angeles-London: University of California Press; repr. as 1-vol. paperback 1986. [http://www.utexas.edu/courses/citylife/readings/philhellenism.pdf]

Holleaux, M. (1921): Rome, la Grèce et les monarchies hellénistiques au III ${ }^{\text {èe }}$ siècle avant J.-C. Paris.

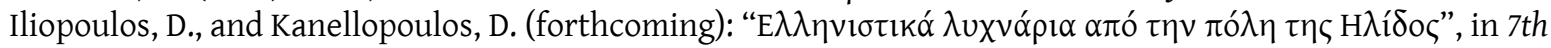
Hellenistic Pottery Meeting, [unpublished poster abstract].

Jameson, M. H., Runnels, C. N., and van Andel, T. H., with M. H. Munn (1994): A Greek Countryside. The Southern Argolid from Prehistory to the Present Day. Stanford, Calif.: Stanford University Press.

Kastler, R. (1997): “Abriss zur hellenistischen Keramik von Elis”, in 4th Hellenistic Pottery Meeting, 21-3.

Kastler, R. (2000): "Die Keramik der Südhalle von Elis und die Problematik der regionalen Keramikchronologie der Region Elis", in 5th Hellenistic Pottery Meeting, 403-16, pls 211-14.

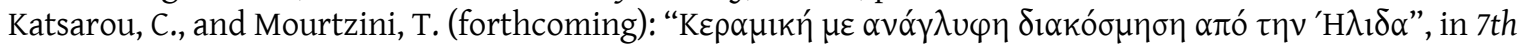
Hellenistic Pottery Meeting, [unpublished poster abstract].

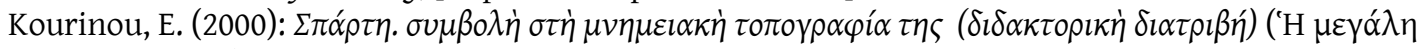
$\left.\beta i \beta \lambda_{10} \theta \eta \dot{\kappa} \kappa\right)$. Athina: Horos.

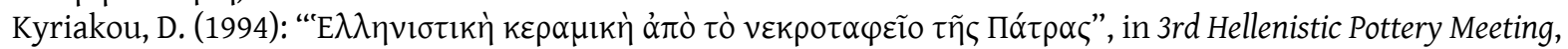
185-95, pls 127-41.

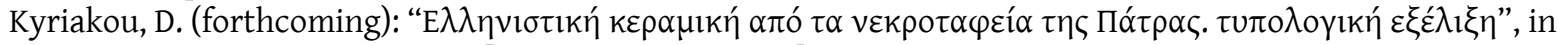
7th Hellenistic Pottery Meeting, [unpublished abstract].

Lakakis, M., and Rizakis, A. D. (1992): “Les grandes étapes de l'occupation du sol de l'Âge de Pierre à l'époque contemporaine", in A. D. Rizakis (ed.), Paysages d'Achaïe, i. Le Bassin du Péiros et la plaine occidentale

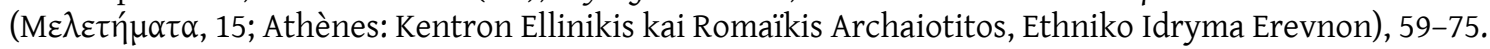

Lang, W. (1878): Peloponnesische Wanderung. Berlin: Gebrüder Paetel.

Langridge-Noti, E., and Prent, M. (forthcoming): "Continuity, connections and change in hellenistic pottery from Geraki in Laconia", in 7th Hellenistic Pottery Meeting, [unpublished abstract].

Leake, W. M. (1830): Travels in the Morea. 3 vols. London: John Murray; repr. Amsterdam: Hakkert, 1968; 
Chicago, Ares, c.2004.

Leake, W. M. (1846): Peloponnesiaca. A Supplement to Travels in the Morea. London: J. Rodwell; repr. Amsterdam: Hakkert, 1967; Chicago, Ares, c.2004.

Leekley, D., and Noyes, R. (1976): Archaeological Excavations in Southern Greece. Park Ridge, NJ: Noyes Press.

Leon-Mitsopoulou, V. (1994): "Keramik der klassischen und nachklassischen Zeit aus der Stadt Elis", in 3rd Hellenistic Pottery Meeting, 159-73, pls 89-105.

Lloyd, J. (1991): "Farming the highlands. Samnium and Arcadia in the hellenistic and early Roman periods", in G. Barker and J. Lloyd (eds), Roman Landscapes. Archaeological Survey in the Mediterranean Region

(Archaeological Monographs of the British School at Rome, 2; London: British School at Rome), 180-93.

Lukes, S. (2004): Power. A Radical View, 2nd edn (Studies in Sociology). London: Palgrave Macmillan.

Ma, J. (1999): Antiochos III and the Cities of Western Asia Minor. Oxford: OUP.

Meyer, E. (1975): "Pheneos", KP iv. 726-7.

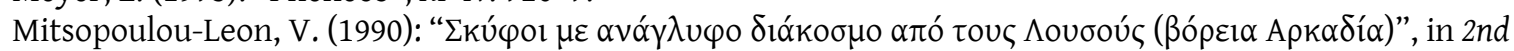
Hellenistic Pottery Meeting, 120.

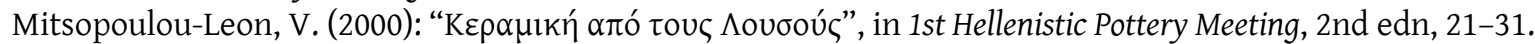

Nielsen, T. H. (2004): “Triphylia”, in M. H. Hansen and T. H. Nielsen (eds), An Inventory of Archaic and Classical Poleis (Oxford: OUP), 540-6.

Ostwald, M. (2000): Oligarchia. The Development of a Constitutional Form in Ancient Greece (Historia Einzelschriften, 144). Stuttgart: Steiner.

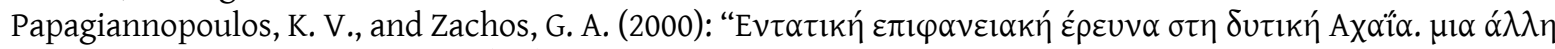

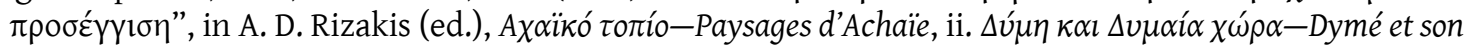

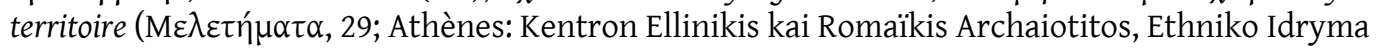
Erevnon), 139-54.

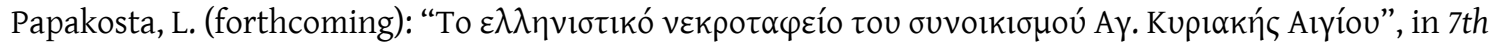
Hellenistic Pottery Meeting, [unpublished abstract].

Penttinen, A. (1996): "The Berbati-Limnes Archaeological Survey: the classical and hellenistic periods", in B. Wells and C. Runnels (eds), The Berbati-Limnes Archaeological Survey 1988-1990 (Skrifter utgivna av Svenska Institutet i Athen, $4^{\circ}-$ Acta Instituti Atheniensis Regni Sueciae, series in 4ํㅜ 44 ; Stockholm/Jonsered: Svenska Institutet i Athen/Åström), 229-83.

Petropoulos, M., and Rizakis, A. D. (1994): "Settlement patterns and landscape in the coastal area of Patras. preliminary report", JRA 7, 183-207.

Philippson, A. (1892): Der Peloponnes. Versuch einer Landeskunde auf geologischer Grundlage (nach Ergebnissen eigener Reisen). Berlin: Friedländer.

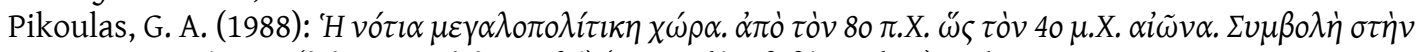

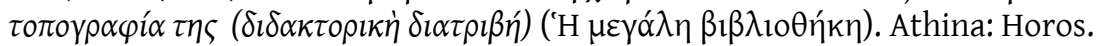

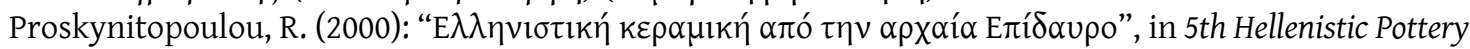
Meeting, 393-402, pls 207-10.

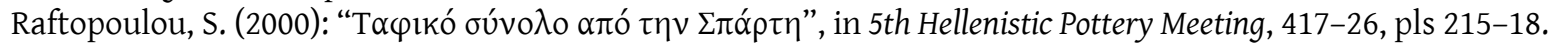

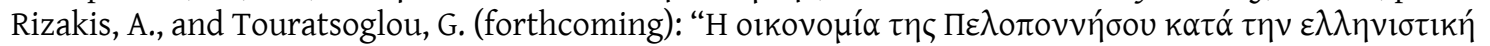

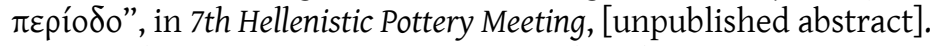

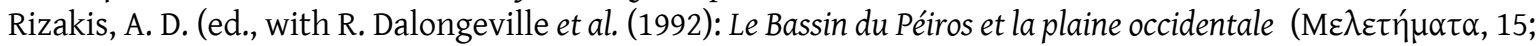
Paysages d'Achaïe, 1). Athènes: Kentron Ellinikis kai Romaïkis Archaiotitos, Ethniko Idryma Erevnon.

Rogl, C. (1997): “Homerische Becher aus der Stadt Elis”, in 4th Hellenistic Pottery Meeting, 317-28, pls 235-8.

Rogl, C. (2004): "Hellenistische Reliefbecher aus der Stadt Lousoi. die Erzeugnisse der lokalen Werkstätte(n) [poster]", in 6th Hellenistic Pottery Meeting, 771.

Ross, L. (1841): Reisen und Reiserouten durch Griechenland, i. Reisen im Peloponnes. Der ager Dentheliates, Phliasia, Sikyonia, Arkadien, Theile von Argolis, Thyreatis, Theile von Lakonikae. Berlin: Reimer.

Rostovtzeff, M., with P. M. Fraser (1953): The Social and Economic History of the Hellenistic World, 2nd edn. 3 vols. Oxford: Clarendon Press.

Roy, J. (2004): “Elis", in M. H. Hansen and T. H. Nielsen (eds), An Inventory of Archaic and Classical Poleis (Oxford: OUP), 489-504.

Roy, J., Lloyd, J. A., and Owens, E. J. (1989): "Megalopolis under the Roman empire", in S. Walker and A. Cameron (eds), The Greek Renaissance in the Roman Empire (BICS suppl. 55; London: Institute of Classical Studies), 146-50, pl. 56.

Sanders, G. D. R., and Whitbread, I. K. (1990): “Central places and major roads in the Peloponnese”, ABSA 85, 333-62.

Schauer, C. (1997): "Ein hellenistischer Brunnen in Olympia”, in 4th Hellenistic Pottery Meeting, 24-31, pls 11-16. Scott, J. (2001): Power (Key Concepts). Cambridge: Polity Press.

Shipley, D. G. J. (2000): “The extent of Spartan territory in the late classical and hellenistic periods", ABSA 95, 367-90. 
Shipley, D. G. J. (2002a): “Hidden landscapes. Greek field survey data and hellenistic history”, in D. Ogden (ed.), The Hellenistic World. New Perspectives (Swansea/London: Classical Press of Wales/Duckworth), 177-98.

Shipley, D. G. J. (2002b): "The survey area in the hellenistic and Roman periods", in W. Cavanagh et al., Continuity and Change in a Greek Rural Landscape. The Laconia Survey, i. (BSA Supplementary Volumes, 26; London: British School at Athens), 257-337.

Shipley, D. G. J. (2005): "Between Macedonia and Rome. political landscapes and social change in southern Greece in the early hellenistic period", ABSA 100, 315-30. [https://lra.le.ac.uk/handle/2381/2850]

Shipley, D. G. J. (2006): "Landscapes of the ancient Peloponnese. a human-geographical approach", Leidschrift 21.1, 27-43. [www.leidschrift.nl]

Tarn, W. W. (1913): Antigonos Gonatas. Oxford: Clarendon Press; repr. 1969.

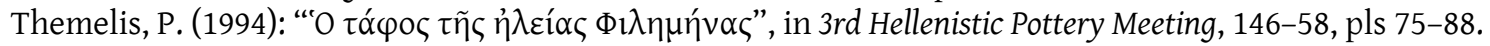

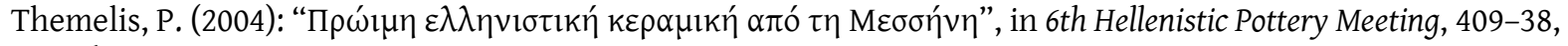
pls $183-94$.

Tuan, Y.-F. (1974a): "Space and place. humanistic perspective”, in C. Board et al. (eds), Progress in Geography. International Reviews of Current Research, vi. (London: Edward Arnold), 211-52.

Tuan, Y.-F. (1974b): Topophilia. A Study of Environmental Perception, Attitudes, and Values. Englewood Cliffs, NJLondon: Prentice Hall.

Tuan, Y.-F. (1977): Space and Place. The Perspective of Experience. London/Minneapolis: Edward Arnold/University of Minnesota Press; repr. 2001.

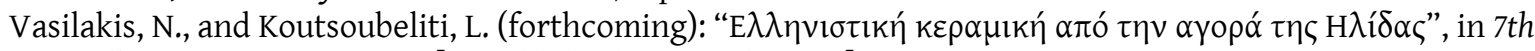
Hellenistic Pottery Meeting, [unpublished poster abstract].

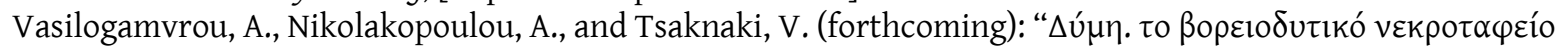

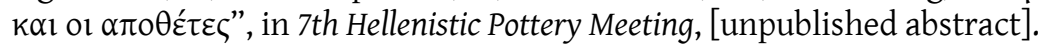

von Freyberg, B., Reinhard, W. A., Stadtmüller, G., Bohtz, H., and Gerke, F. (1944): Der Peloponnes. Landschaft, Geschichte, Kunststätten (von Soldaten für Soldaten). Athen: [Wehrmacht].

Walbank, F. W. (1957): A Historical Commentary on Polybius, i. Commentary on Books I-VI. Oxford: Clarendon Press. Whitley, J. (2002-3): “Archaeology in Greece 2002-2003”, AR 49, 1-88.

Wright, J. C., Cherry, J. F., Davis, J. L., Mantzourani, E., Sutton, S. B., and Sutton, R. F., Jr. (1990): "The Nemea Valley Archaeological Project. a preliminary report", Hesp. 59.4, 579-659.

Wyse, T., Sir (1865): An Excursion in the Peloponnesos in the Year 1858 (ed. W. M. Wyse). 2 vols. London: Day \& Son. Zehbe, I. (1988): "Ein "megarischer" Reliefbecher von Asine", OAth 17, 217-24. 